\title{
STATISTICAL INDICES OF LAND USE CHANGES AND NUTRIENTS BALANCE OF TOMATOES AND PEPPERS PRODUCTION IN JORDAN VALLEY AND HIGHLANDS (1999-2019)
}

\section{MOHUNNAD MASSIMI}

\author{
${ }^{1}$ University of Debrecen, Institute of Plant Protection, Kerpely Kálmán Doctoral School of \\ Horticultural Sciences \\ *Email: mohunnad.massimi@agr.unideb.hu
}

Received 13 July 2021, accepted in revised form 22 October 2021

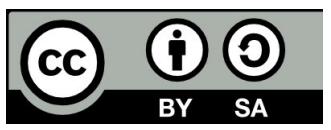

\begin{abstract}
Climate change has caused pressure on water resources in Jordan. This was accompanied by the Syrian refugee crisis during the period 2009 to 2019. This descriptive study was conducted in the University of Debrecen, during the years 2020 and 2021 within the course of sustainable land use by collecting official statistical data from reliable sources in Jordan on the production of tomato, pepper, and paprika during five years 1999, 2004, 2009, 2014 and 2019 to compare the change in land use, crop sown structure, country production, unit area average yield and estimation of unit area pollution with major nutrients. The study showed an increased land used for the production of vegetables by $(+38 \%)$ during the period from 2004 to 2014, high productivity per hectare for three crops from 2014 to 2019. Jordan had the highest tomato and paprika crop yields in 2014. The reason is due to the increase in the local and global demand for these crops along with other reasons, which have promoted the use of mass production agricultural techniques, the most important of which is chemical fertilization. The study indicated the accumulation of phosphorus and potassium in soils, with possible salinization resulting from water quality problems as well.
\end{abstract}

Keywords: Jordan, Land Use Change, Nutrients, Sown Structure, Yield

\section{Introduction}

Jordan is an Arab country in Western Asia located on the Jordan River's east bank, between $29^{\circ}$ and $34^{\circ} \mathrm{N}$ and $34^{\circ}$ and $40^{\circ}$ E According to Food and Agricultural Organization estimates (FA0, 2016), Jordan has an area of 8932 thousand hectares, a land area of 8878 thousand hectares, with 1066 thousand hectares of agricultural land and 97.5 thousand hectares of forest land.

Jordan has a wide range of climates.
Summers are hot and dry, lasting from May to September, with temperatures averaging around $32{ }^{\circ} \mathrm{C}$ and occasionally exceeding $40{ }^{\circ} \mathrm{C}$, especially in July and August. The winter season, which lasts from November to March, is mild, with temperatures average approximately $13{ }^{\circ} \mathrm{C}$. In some Western high areas, winter also brings regular rains and snowfall.

Jordan is the world's second poorest country in terms of water resources per capita, and the inflow of Syrian refugees has 
exacerbated the scarcity of water resources. Jordan's predicted water supply and demand were compared by Soazic (2014) during (2015-2025). According to the latter study, water demand is expected to increase from 1229 million $\mathrm{m}^{3}$ in 2015 to 1398 million $\mathrm{m}^{3}$ in 2020 and up to 1559 million $\mathrm{m}^{3}$ in 2025 .

Increased water scarcity will most certainly reduce cultivated crop yields and put livestock production at risk. Due to the lack of water, land use and crop structure will alter. The development of water resources to expand Jordan's supply is a primary priority for decision-makers. Adaptation methods at the user level are aimed at reducing demand by enhancing water efficiency and adopting appropriate farming patterns that use less water while producing more food (Al-Bakri et al. 2013). As a result, Jordan's government has maintained a strong focus on food security. The production of fruits, vegetables, and field crops is the main emphasis of the food security strategy.

The land is becoming more scarce as demand for numerous land uses and ecological services grows. Concerns about food security and renewable energy are driving calls for agricultural land to be converted to other uses such as reforestation and biofuel production (Metternicht, 2018).

It has previously been reported that the potential impacts of global climate change, such as long-term drought, mass migration, and abrupt climatic shifts, could lead to international instability in affected regions, posing a threat to US national security as well as security, economic, and environmental interests (Silberstein and Maser, 2014).

Similarly, in Jordan, there is a critical need for sustainable land use studies that indicate sown structure of cultivated plants due to climate change and expectations for drought conditions characterized by lower rainfall and less water for irrigation in some regions, such as the eastern arid parts of Jordan.

The structure of cultivated plants sown in Jordan is linked to the water condition and drought, as previously stated. Because the amount of water has a significant impact on the usage of land and the diversity of plants, government and farmer decisions are also influenced. Jordan is anticipated to experience climate change, drought, and water scarcity. This information was documented in the most notable local sources (Wigley, 2008; Massimi et al. 2018 a; Massimi et al. 2018 b), as well as in the international reference (Soazic, 2014). A local modeling study reported that climate change in Jordan would be extreme in terms of decreased precipitation and increased air temperature, according to future climate estimates. Minimum air temperatures would rise by $2.0-4.8{ }^{\circ} \mathrm{C}$ on average, while maximum air temperatures would rise by 2.4 $-5.4{ }^{\circ} \mathrm{C}$ (Al-Bakri et al. 2021). The effect of climate change as a major driver in land use is also highlighted in prominent international references that explore the topic of planning and land use (Silberstein and Maser, 2014; and Metternicht, 2018).

The cultivated regions of fruit trees, various field crops, and horticultural vegetable crops are the three sectors (branches) of plant production in Jordan. Irrigated and rainfed crops are separated in each location. Because of climate change and less reliance on rainfed agriculture, the area of plants exploited for producing fruit trees, field crops, and vegetables under rainfed circumstances fell from 1999 to 2019 (DOS, 2021). Rainfed cultivation of arable field crops is being reduced due to climate change. As a result, additionalland has been irrigated, particularly in the highlands. It was suggested that in the Jordan highlands, a planned cropping design be used to enhance water use efficiency (AlBakri 2015). Arable agricultural production refers to the systematic utilization of land to cultivate crops (Future Learn, 2021). To maintain a consistent supply of their valued commodity, farmers monitor the fertility of their land and undertake a process of preparation after the previous year's harvest. Here are some examples of arable crops and their uses: grain crops (wheat, maize, and barley) are cultivated for food starch grains; legume pulse crops (lentil, beans, peas, 
chickpeas, and faba-beans) are grown for edible seeds high in protein; oilseed crops (safflower, and sunflower) are grown for oil extraction from their seeds. Crops grown for animal feed, either fresh or preserved (alfalfa, Sudan-grass, ryegrass, sorghum, silage corn, and clovers); fiber crops grown for non-food use (flax); tuber crops grown for edible underground parts (potato, radish, carrot, and turnips). During the range limits of comparable years of 1999 and 2019, wheat and barley were the most common arable field crops in Jordan (DOS, 2021).

On the other hand, many studies in Jordan show a desire to improve vegetable crop yields and quality (Massimi and Al-Bdour, 2018). There are 3 seasons for the production of vegetables such as tomatoes, peppers, and paprika in Jordan, which is the October period in the Jordan Valley (the period time during which the cultivation of temporary crops takes place of vegetables, which fall between August and the end of November). (Al-Khamissi) the period in the Jordan Valley is the period time during which the process of planting temporary crops from vegetables, falls between December and the end of July. Finally, the winter loop in the highlands, which is defined as the period time during which temporary crops of vegetables are planted that fall between September and the end of January.

The Jordan Valley region was the primary producer of vegetables previously. Jordan Valley is significant because it produces during the winter and spring seasons. However, for vegetable cultivation, the highlands became the primary irrigated areas in Jordan. Tomato, squash, eggplant, cucumber, potato, cabbage, cauliflower, pepper, paprika, faba-bean, common bean, peas, cowpeas, Jew Mallow, okra, lettuce, melon, watermelon, spinach, green and dry onions, American cucumber, turnip, carrot, parsley, and radish are among the vegetables grown in Jordan (DOS, 2021). Tomato, potato, eggplant, cauliflower, squash, cucumber, and dry onion are the most common vegetable crops in Jordan in 2019, according to official figures. These crops are fertilized with the key nutrients nitrogen $(\mathrm{N})$, phosphorous $\left(\mathrm{P}_{2} \mathrm{O}_{5}\right)$, and potassium $\left(\mathrm{K}_{2} \mathrm{O}\right)$ during each cropping season. Nutrient balances reveal environmental stresses. A nutrient deficiency (negative value) indicates that soil fertility is deteriorating. A nutrient surplus (positive data) indicates that the soil, water, and air are potentially polluted. A surplus of nutrients over the immediate crop and pasture needs, on the other hand, can result in nutrient losses, which can be a source of both economic inefficiencies in nutrient use by farmers and potential environmental impact through water or air pollution.

Massimi and Radocz (2020) stated that because nutrients can be delivered to plant tissues during important periods of plant growth, foliar fertilization is theoretically more environmentally friendly and focused than soil nutrients fertilization. In conclusion, foliar treatment techniques in the development of horticultural plants are an important strategy for integrated pest management, environmentally sustainable practices, and healthy food production.

This descriptive study aims to shed light on the official statistics related to the areas and productivity of vegetable crops in Jordan, specifically tomato, pepper, and paprika crops during period time 1999 to 2019 while addressing the causes of landuse change such as climate change, low rainfall, scarcity of water resources and the population explosion resulting from the Syrian refugee. With the problems arising from the use of agricultural production techniques, the most important of which is the problem of pollution resulting from fertilizing the major elements of nitrogen, phosphorous, and potassium, and the need to use foliar fertilization as an ideal alternative to this issue, or using natural sources such as compost, and fermented manure to protect the soil instead of increasing its consumption. 


\section{Methodology}

All the original raw data, descriptive statistics, and processed information in this paper were taken from an official and approved source of the Jordanian government, which is the official website of the Department of Statistics (DOS, 2021), which provides reliable data on plant production in Jordan from 1995 to 2019.

Those included the areas cultivated (hectares) and productivity of the unit area (tons per hectare) and the Kingdom's total production (tons) of tomatoes, peppers, and paprika in the following study years: 1999, 2004, 2009, 2014, and 2019. Total productions and average yields means and medians were calculated using mathematical functions in Excel spreadsheets as described by Miller (2012) and Carlberg (2014).

The ratio of the area of tomatoes, peppers, and paprika to the total area of vegetables in Jordan for the years 1999, 2009, and 2019 was deduced mathematically, and it was expressed in circular sectors using figures showing the ratios, where the term sowing structure was used (Figures 1-3).
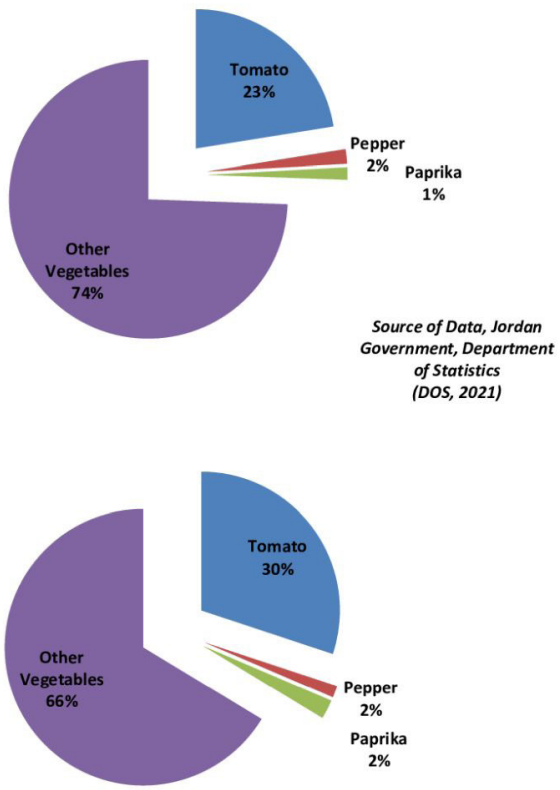

Source of Data, Jordan

Government, Department

of Statistics

(DOS, 2021)

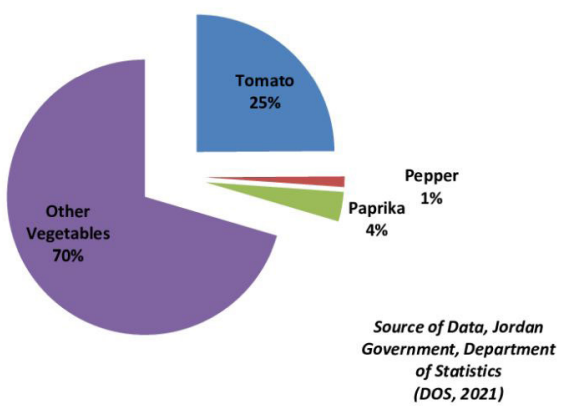

Fig. 1-3. Sowing structure (\%) and ratio for tomato, pepper, and paprika in Jordan (1999), (2009), and (2019) 
The percentage of increase and change in the area of vegetable production was radically evident between 2004 and 2014, where the following statistical equation was used to calculate and express it:

\section{Percent of Increase $=[$ Increase $/$ Original Number $] \times 100$

The research employed regression and correlation approaches to derive mathematical connections that explain how the output of vegetables in general, and the three crops in particular, has been influenced by the population increase during the last two decades (1999-2019) in Jordan (Figures 4 , and 5).

The three main nutrients $\left(\mathrm{N}, \mathrm{P}_{2} \mathrm{O}_{5}\right.$, and $\left.\mathrm{K}_{2} \mathrm{O}\right)$ for fertilizing vegetables and producing one ton of each crop are, according to scientific references issued by the National Center for Agricultural Research and Technology Transfer (NCARTT, 2005) and Jordan University of Science and Technology (JUST, 2005). To produce one ton of tomatoes, the fertilization is $2.8,1.3$, and $3.8 \mathrm{Kg}$ of $\mathrm{N}, \mathrm{P}_{2} \mathrm{O}_{5}$, and $\mathrm{K}_{2} \mathrm{O}$, respectively. On the other hand, pepper and paprika are fertilized with 2.1, 1.1, and $4.2 \mathrm{Kg}$ per ton of crop production from the three aforementioned nutrients. Jordan's $\left(\mathrm{P}_{2} \mathrm{O}_{5}\right)$ nutrient balance equivalent is considered to be (1.12), and Jordan's $\left(\mathrm{K}_{2} \mathrm{O}\right)$ nutrient balance equivalent is similarly assumed to be (1.3) according to the Food and Agriculture Organization of the United Nations (FAO) published report in 2003 (FAO, 2003).

\section{Acting Nitrogen $=[$ Total Nitrogen $\times$ Nitrogen Equivalent]

The previous formula was used in a balanced analysis of nitrogen added from chemical fertilizers for all crops. According to the FAO, fertilizers have a nitrogen equivalent of one (by definition) (FAO, 2003). Farmers fertilize these crops in the same amounts every season. As a result, the amount of nitrogen entering is equal to the amount of nitrogen generated (theoretically), and the balance is zero.
In this study, it was assumed that the input to the agricultural process from the elements of $\mathrm{P}_{2} \mathrm{O}_{5}$ and $\mathrm{K}_{2} \mathrm{O}$ and the one that the crop took are equal. The formula for calculating output is to multiply removal by the balance equivalent:

$$
\begin{aligned}
& \text { Output }=[\text { Removal } \times 1.12] \text { for } \mathrm{P}_{2} \mathrm{O}_{5} \\
& \text { Output }=[\text { Removal } \times 1.30] \text { for } \mathrm{K}_{2} \mathrm{O}
\end{aligned}
$$

The previous readings were simplified to calculate the balance of three major nutrients of the approved unit area in (hectares).

The balance equation, in short, is (FAO, 2003):

\section{Balance of $\left(\mathrm{N}, \mathrm{P}_{2} \mathrm{O}_{5}\right.$, and $\left.\mathrm{K}_{2} \mathrm{O}\right)\left(\mathrm{kg} \mathrm{ha}^{-1}\right)=$} [Output - Input] (5)

The technique of evaluating total production for each crop over study years to detect any consistent results or patterns was done using trend analysis. It can be used to create a strategy for responding to these trends in light of anticipated environmental challenges such as soil nutrient accumulation (Figures 7, 8, 9, and 10).

\section{Results and Discussion}

From Table (1) and Figures 1 to 3, the areas of the three crops in the five years appear documented according to the Jordanian Department of Statistics (DOS, 2021).

The sown structure of the crop is shown, i.e. the ratio expressed in the area of the land cultivated from each cash crop to the total area of vegetables according to the year (1999) in Figure (1), year (2009) in Figure (2), and the year (2019) in Figure (3).

The most important thing that can be observed in the readings from Table (1) is the increasing percentage of change in land uses for growing vegetables in general by $(+38 \%)$ from 2004 to 2014 .

During this period (2004-2014), the migrations of Syrians increased, droughts rates increased, and rainfall amounts decreased. At the same time, the demand for improved and produced varieties in high quantities and excellent quality increased 
to meet the needs of the local community and export. According to the Department of Statistics website (DOS, 2021), 26 types of common vegetables are grown in Jordan.

The Jordanian Ministry of Agriculture is now directing the issuance of Jordanian Good Agricultural Practices (Jordan GAP) regulations that follow the global good agricultural practices (Global GAP) model, where vegetable crops rotations programs are used to meet the requirements for obtaining these certificates.

This fact was highlighted by Massimi and Al-Bdour (2018) in a study that recommended the development of a database and computerized programs for crop rotation design by introducing basic scientific data in line with production policy, import and export strategies, to ensure that the local product has a preferential price throughout the year to avoid flooding the local market with imported crops, also to handle the risk of numerous agricultural pests, insects, and weeds, as well as to preserve soil fertility and water retention, using the principle of input management and the costs management of agricultural inputs, particularly regarding irrigation, water, and fertilizer prices.

All the previous challenges related to increasing production in quantity and quality were a strong motive to raise the level of productivity, especially the issue of Syrian refugees and the increase of pressure on water resources.

The Jordan Valley is home to a lot of protected vegetable farming. Figures (1-3) depict the sown structure (hectares) for each cash crop (tomato, pepper, and paprika) in Jordan during the years 1999, 2009, and 2019.

There is no huge change in the percentage of areas planted with the tomato crop, as it reached $23 \%$ of the total vegetables in 1999 , $30 \%$ in 2009, and 25\% in 2019 (Figures 1-3).

It is noted that the huge jump in tomato production was during 2009 as a result of the increase in the production of vegetables in general during an era (2004-2014).

The percentage of pepper cultivations, both hot and sweet, remained close and ranged between 3\% (1999) to $5 \%$ (2019). The reason for this little increase is due to the increased interest in the improved and colored varieties of paprika as a result of contracts for export according to specifications of (Global GAP), and for the supply of local restaurants and hotels.

Some researchers explained that the cultivated areas did not change is caused of the Jordan Valley Authority's control over

Table 1. Jordan's total cultivated area (hectares) of the three crops in five specific years

\begin{tabular}{cccccc}
\hline Area Planted (hectares) & 1999 & 2004 & 2009 & 2014 & 2019 \\
\hline Tomato & 8029.86 & 9022.91 & 12394.37 & 14564.08 & 8319.9 \\
Pepper & 596.84 & 609.93 & 559.01 & 546.99 & 406.94 \\
Paprika & 507.09 & 619.81 & 917.89 & 1373.01 & 1151.73 \\
Other Vegetables & 26607.83 & 26651.51 & 27308.15 & 34384.65 & 23534.49 \\
Total Vegetables & 35741.62 & 36904.16 & 41179.42 & 50868.73 & 33413.06 \\
\hline
\end{tabular}

Table 2. Jordan's total production (tons) of the three crops in five specific years

\begin{tabular}{cccccccc}
\hline $\begin{array}{c}\text { Production } \\
\text { (tons) }\end{array}$ & 1999 & 2004 & 2009 & 2014 & 2019 & Median & Mean \\
\hline Tomato & 293287.4 & 449486.5 & 654306.4 & 744601.9 & 496215.7 & 496215.7 & 527579.6 \\
Pepper & 12856.8 & 17773.8 & 14292.8 & 3098.4 & 10015.4 & 12856.8 & 11607.44 \\
Paprika & 9895.9 & 21328.5 & 29380.2 & 63004.2 & 55770.6 & 29380.2 & 35875.88 \\
\hline
\end{tabular}


Table 3. Average yields (tons ha-1) of the three crops in five specific years

\begin{tabular}{cccccccc}
\hline Yield (tons ha $^{-1}$ ) & 1999 & 2004 & 2009 & 2014 & 2019 & Median & Mean \\
\hline Tomato & 37 & 50 & 53 & 51 & 60 & 51 & 50.2 \\
Pepper & 22 & 29 & 26 & 6 & 25 & 25 & 21.6 \\
Paprika & 20 & 34 & 32 & 46 & 48 & 34 & 36 \\
\hline
\end{tabular}

the size of holdings in the Jordan Valley region. The Jordan Valley area's reclaimed areas are likewise constrained as water resources dwindle. However, any change in the increase of vegetable production is due to the expansion of agriculture in the highlands and eastern desert (Al-Bakri, 2015). In the highlands, the winter period is generally planted, which is defined as the season between September and the end of January when temporary vegetable crops are sown.

In Table (2), the amount of Jordan's production of the three cash crops in the years 1999, 2004, 2009, 2014, and 2019 is shown in tons. Jordan produced the highest productivity of tomato and paprika crops in 2014. While the highest production of hot pepper was recorded in 2004. The average value of the total yield to tomato crop was reached (527579.6 tons). While the average values for the total productivity of pepper and paprika crops were (11607.44, and 35875.88 tons, respectively). Tables (1, and 2) are combined in the appendix (Figure 11).

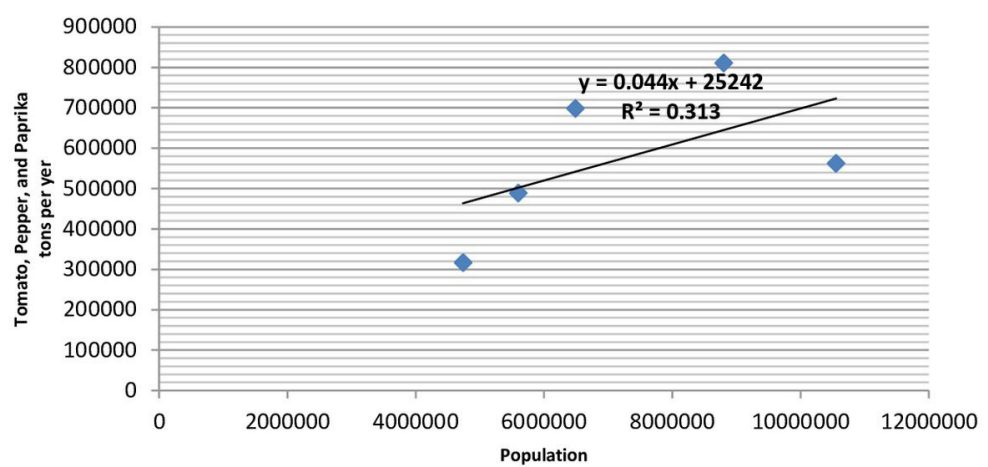

Fig. 4. The correlation and regression of population relationship with the productivity of the three crops during study research years

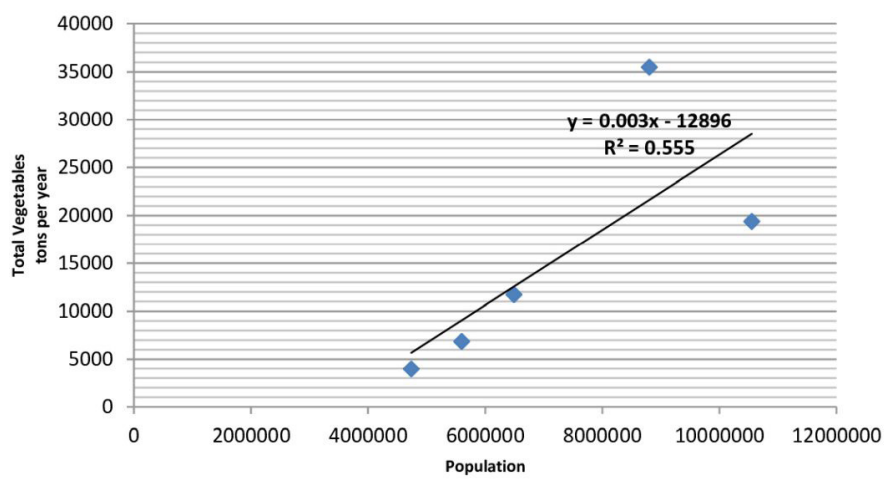

Fig. 5. The correlation and regression of population relationship with the productivity of all vegetables during study research years 


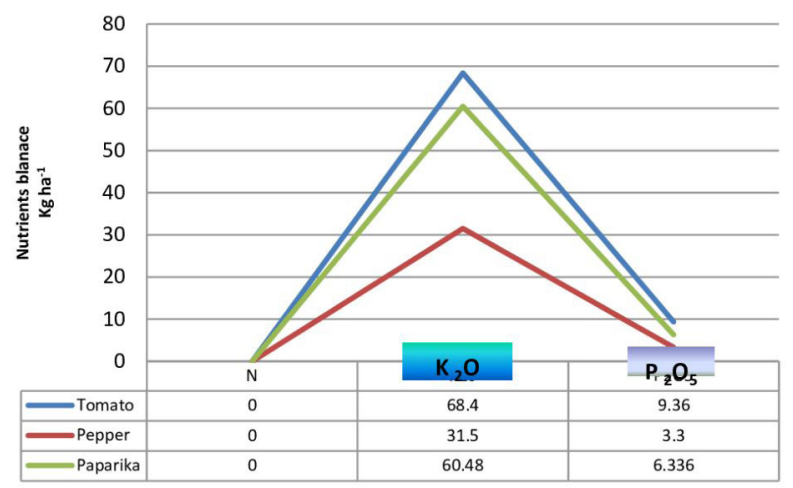

Fig. 6. The balance of the three nutrients $\left(\mathrm{Kg} \mathrm{ha}^{-1}\right)$ for the three crops in Jordan soils (2019)

Far from the total measurements of the national production capacity of the three cash crops. In Table (3), the average yield unit area for each crop in each of the five years under study was estimated.

It appears from the values that the average productivity per unit area (ha) of tomato and paprika crops increased in each year following the previous one. Where it reached the highest value in the year 2019 (Table 3).

However, it is clear from the table that the average productivity per hectare of the pepper crop decreased in 2014 and then increased in 2019, where the average of the five readings was about 21.6 (ton ha-1). It can be generalized as a result that there was a jump in the production of tomatoes, peppers, and paprika that started in 2004 and continued until 2014. It is necessary to note that modern agricultural production techniques have increased the productivity of the unit area in 2019. This is consistent with the government's directions to improve production in quantity and quality to meet local and global requirements (Massimi and Al-Bdour, 2018). It's worth noting here that strategies to conserve water resources in the future require planning crop rotations and their pattern in highlands (Massimi and Al-Bdour, 2018) so that cultivation does not expand as much as it is improved in using innovations to increase highlands production and prevent the waste of water resources.

Jordan's population expanded from $4,738,000$ in 1999 to $10,554,000$ in 2019, resulting in increased output of tomatoes, peppers, and paprika in particular (Figure 4), as well as vegetables in general (Figure 5). Jordan's overall crop production is dependent on population inflation, as evidenced by a regression coefficient of $55.5 \%$ (Figure 5). The regression ratio of 55.5 (correlation

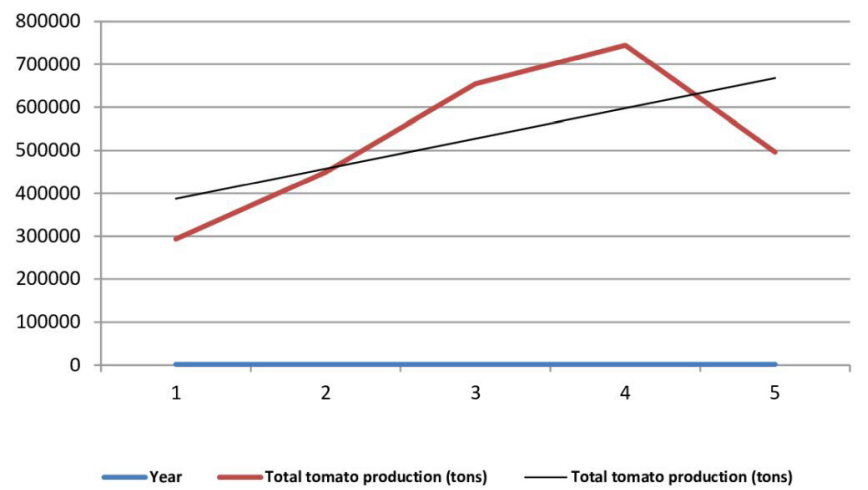

Fig. 7. Trend analysis of total tomato production (tons) in Jordan during the years of research (1999, 2004, 2009, 2014, and 2019) 
is $74.5 \%$ ) is explained by a high positive correlation. Other variables contribute to the rise in vegetable output, such as population growth and the expansion of vegetable cultivation in the highlands. Theoretically, current agricultural technology, such as chemical fertilizers, can be claimed to have a key part in the increase in vegetable production.

The difference between nutrient inputs (mainly livestock manure and fertilizers) and nutrient outputs in a farming system is referred to as the nutrient balance (the uptake of nutrients for crop and pasture production). Tomato, potato, eggplant, cauliflower, squash, cucumber, and dry onion are the most common vegetable crops in Jordan in 2019, according to official figures.
These crops are fertilized with the key nutrients nitrogen $(\mathrm{N})$, phosphorous $\left(\mathrm{P}_{2} \mathrm{O}_{5}\right)$, and potassium $\left(\mathrm{K}_{2} \mathrm{O}\right)$ during each cropping season.

According to figure (6), there are no problems in the soils of Jordan concerning nitrogen, but the accumulations are for other fertilizers $\left(\mathrm{K}_{2} \mathrm{O}\right.$ and $\left.\mathrm{P}_{2} \mathrm{O}_{5}\right)$ in 2019.

The balance amount of phosphorous pentoxide $\left(\mathrm{P}_{2} \mathrm{O}_{5}\right)$ in Jordanian soils due to tomato cultivation was $\left(9.36 \mathrm{~kg} \mathrm{ha}^{-1}\right)$, because of paprika plantings was (6.34 $\left.\mathrm{kg} \mathrm{ha}^{-1}\right)$, and due to peppers growing $\left(3.3 \mathrm{~kg} \mathrm{ha}^{-1}\right)$.

However, the potassium dioxide $\left(\mathrm{K}_{2} \mathrm{O}\right)$ values were higher for the three crops in 2019 , reaching $\left(68.4 \mathrm{~kg} \mathrm{ha}^{-1}\right.$ in tomato field, $31.5 \mathrm{~kg} \mathrm{ha}^{-1}$ in pepper, and $60.48 \mathrm{~kg} \mathrm{ha}^{-1}$ in paprika fields).

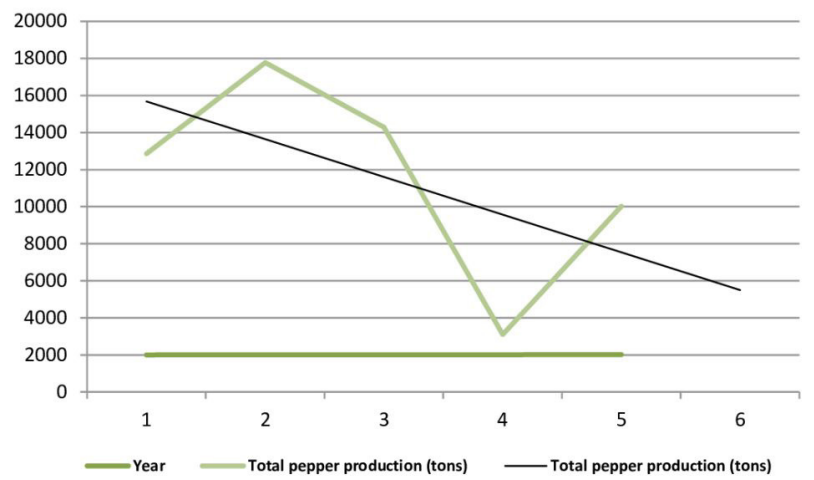

Fig. 8. Trend analysis of total pepper production (tons) in Jordan during the years of research (1999, 2004, 2009, 2014, and 2019)

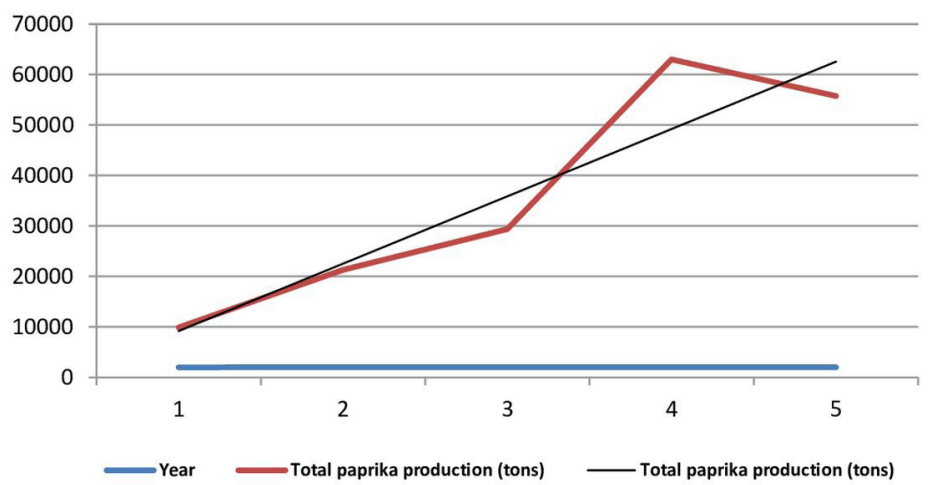

Fig. 9. Trend analysis of total paprika (tons) in Jordan during the years of research (1999, 2004, 2009, 2014, and 2019) 


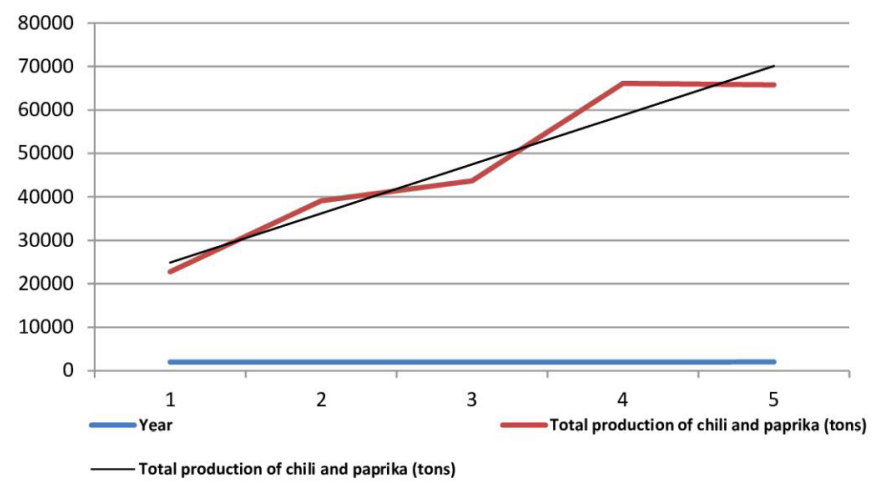

Fig. 10. Trend analysis of total chili and paprika (tons) in Jordan during the years of research (1999, 2004, 2009, 2014, and 2019)

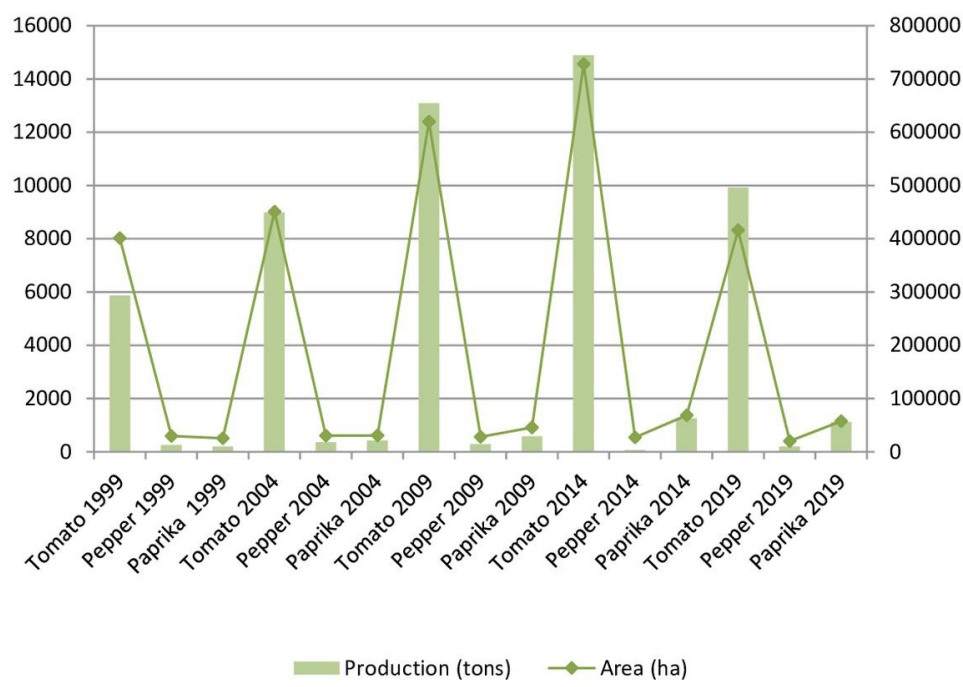

Fig. 11. The area of each crop and its production combined during the years of research

Nutrient balances reveal environmental pressures. A nutrient shortage (low value) indicates that soil fertility is dwindling. A nutrient surplus (positive data) indicates that pollution of the soil, water, and air is a possibility.

A surplus of nutrients over the immediate crop needs, on the other hand, can result in nutrient losses, which can be a source of both economic inefficiencies in nutrient use by farmers and potential environmental impact through water or air pollution.

According to the study's findings (Ammari et al. 2013), the Jordan Valley's soils are salty in about $63 \%$ of cases, with almost
$46 \%$ being moderate to moderately saline. The salinity indicator in the soil is not alone as an indication of soil contamination with fertilizers, but the contamination of irrigation water expresses this as well. There are 67 saline water springs in Jordan, with 23 in the Jordan River Basin, 33 in the Dead Sea Basin, 8 in the Wadi Araba Basin, one in the Azraq Basin, and two in the Al-Jafr Basin (Moustafa et al. 2007). This water is used to irrigate vegetables, as well as water from the King Talal Dam mixed with treated wastewater. The problem of salinization is a complex problem resulting from excessive fertilization and over-pumping of water. Mixing treated wastewater reduces the effect 
of the problem, but the poor management of soil nutrients with heat and drought stresses increases the level of soil salts. When considering that phosphate ions are only absorbed by plant roots when they are dissolved in soil moisture, the problem of salinity with phosphorus gets even worse. In addition, the optimal soil acidity for improving phosphorus nutrient readiness is 7. Otherwise, phosphorus will build up in the soil. Non-sandy and alkaline soils are a place for potassium retention also. It is projected that an increase in these two elements in the soil will result in poor absorption of other elements (antagonistic impact), resulting in soil and water pollution, as well as a lack of financial resource management on the farm.

Following a linear trend analysis, it was discovered that there is a future tendency in expanding tomato (Figure 7), hot pepper, and paprika production (Figures 9, and 10) together. The problem of phosphorus and potassium pollution in the soil is anticipated to worsen.

\section{Conclusion}

From 2004 to 2014, the study found an increase in area used for vegetable production of $(+38 \%)$, as well as high yield per hectare for cash crops of tomato, pepper, and paprika from 2014 to 2019. Jordan's tomato and paprika crop yields were the greatest in 2014. The direct reason is due to an increase in local and global demand for these crops, which resulted from population growth and the influx of Syrian refugees, putting additional strain on water supplies, in addition to the indirect effects of climate change, which include rising average temperatures and decreasing precipitation. These have pushed for the adoption of mass-production agriculture practices, the most prominent of which being chemical fertilization. As a result, phosphorus and potassium accumulated in soils. If nitrate accumulates in the soil, repels its negative charges, and enters the groundwater, it can be claimed that it is the single and expected source of contamination. Drought, overpumping, and over-fertilization, on the other hand, induce a rise in phosphorus and potassium in the soil. Potassium availability reduces plant absorption of magnesium and boron. The presence of phosphorus nutrient lowers plant uptake of potassium and calcium, as well as iron, copper, and zinc. The Institute of Plant Protection at the University of Debrecen recommends the use of foliar fertilization for tomato, pepper, and paprika production in Jordan to reduce the impact of this environmental problem, it is also suggested to avoid the accumulation of nutrients in both the soil and water and the waste of money, time, and effort, is to conduct soil testing and schedule fertilizer according to the demands of the plant before planting.

\section{Acknowledgments}

The University of Debrecen's Doctoral School of Horticultural Sciences' Institute of Plant Protection supported this research, which was financed by the Stipendum Hungaricum Scholarship, Hungary in 2020/2021. Dr. Janos Nagy, the training course of sustainable land use supervisor, and Dr. László Radócz, the dissertation credits supervisor, deserve special recognition.

\section{References}

Al-Bakri, J. (2015): Crop mapping and validation of ALEXI-ET in Azraq and Mafraq areas. A report for Regional Coordination on Improved Water Resources Management and Capacity Building, Ministry of Water and Irrigation, Amman, Jordan.

Al-Bakri, J.-Farhan, I.- Al-Qinna, M.- Al-Karablieh, E.Bergouli, K.- McDonnell, R. (2021): Assessment of climate changes and their impact on barley yield in Mediterranean environment using NEX-GDDP downscaled GCMs and DSSAT. Earth Systems and Environment. 1-16.

Al-Bakri, J.- Salahat, M.- Suleiman, A,- Suifan, M.Hamdan, M.R.- Khresat, S.- Kandakji, T. (2013): Impact of climate and land use changes on water and food security in Jordan: Implications for transcending "the tragedy of the commons". Sustainability. 5(2):724-748. https://doi. org/10.3390/su5020724. 
Ammari, T.- Tahhan, R.- Abubaker, S.- Al-Zu'bi, Y.Tahboub, A.- Ta'any, R.- Abu-Romman, S.- AlManaseer, N.- Stietiya, M.H. (2013): Soil salinity changes in the Jordan Valley potentially threaten sustainable irrigated agriculture. Pedosphere. 23(3):376-84.

Carlberg, C. (2014): Statistical analysis: Microsoft Excel 2013. Que Publishing. USA-IndianpolisIndiana.

Department of Statistics, Government of Jordan. (2021): http://dosweb.dos.gov.jo/ar, 0130.06.2021.

Food and Agricultural Organization of the United Nations. (2003): Fertilizer use by crop in Poland, Food and Agricultural Organization, Italy-Rome.

Food and Agricultural Organization of the United Nations. (2016): Jordan, http://www.fao. org/countryprofiles/index/en/?iso3=JOR, 0130.06.2021.

Future Learn. (2021): https://www.futurelearn. com/info/courses/explore-how-farmersproduce-food-sustainably, 16.03.2021.

Massimi, M.- Al-Bdour, A. (2018): A Short scientific note on the horticultural crops optimum planting dates in Jordan. Egyptian Journal of Horticulture 12/2018; 45(2):337-340. DOI:10.21608/ejoh.2018.6221.1085.

Massimi, M.- Anandhi, A.- Haseeb, M.- Lorenzo, A. (2018 a): Modeling the hybrid seedling performance of forage sorghum and silage corn under Jordan irrigation conditions. Indian Journal of Agricultural Research, 52:71-75. DOI:10.18805/IJARe.A-308.

Massimi, M. - Bader, N.- Khamish, KH. - Al-S'uod, A. (2018 b): Economic analysis for forage agronomic crops grown using treated wastewater in Kherbeh Als-Samra region, Jordan. International Journal of Plant \& Soil Science. 22 (4): 1-9.
Massimi, M.- Radocz, L. (2020): A Brief literature investigations on foliar plant nutrition and its function in the protection of horticultural crops. Hungarian Agricultural Engineering. 38: 63-70. DOI 10.17676/HAE.2020.38.63.

Metternicht, G. (2018): Land use and spatial planning: Enabling sustainable management of land resources. Springer. Switzerland.1.

Miller, S. (2012): Math for the GRE. 3rd Edition. Research \& Education Association. USA-New Jersey.6.

Moustafa, A.T.- Jabarin, A.- Jarrar, A.- Jayyousi, A.- Aycicegi, A.L.- Yolles, D.- Pastemak, D.- Hoffman, G.J.- Tarchitzky, J.- Heakal, M.S.- Dabbas, M.- Kuhn, M. (2007): Salinity management in dry regions: Fundamentals and experiences from Egypt, Israel, Jordan and the Palestinian Authority. Ramallah. Middle East Regional Agricultural Programme. 40.

National Center for Agricultural Research and Technology Transfer NCARTT, and Jordan University of Science and Technology JUST. (2005): Fertigation. (Arabic). Jordan.

Silberstein, J.- Maser, CH. (2014): Land-use planning for sustainable development. 2nd Edition. Taylor \& Francis Group. United Kingdom.115.

Soazic, H. (2014): Jordan's food and water security, http: / / www.futuredirections.org.au. 12.10.2020.

Wigley, T. (2008): MAGICC/SCENGEN 5.3 Software. 